ISSN 1392-3196 / e-ISSN 2335-8947

Zemdirbyste-Agriculture, vol. 107, No. 3 (2020), p. 209-216

DOI $10.13080 /$ z-a.2020.107.027

\title{
Root development of temporary and permanent grasslands and their anti-erosion significance on a hilly terrain
}

\author{
Regina SKUODIENE $\dot{1}^{1}$, Irena KINDERIENE ${ }^{1}$, Donata TOMCHUK ${ }^{1}$, Jonas ŠLEPETYS ${ }^{2}$, \\ Danutė KARČAUSKIENË ${ }^{1}$ \\ ${ }^{1}$ Lithuanian Research Centre for Agriculture and Forestry, Vėžaičiai Branch \\ Gargždų 29, Vèžaičiai, Klaipèda distr., Lithuania \\ E-mail: regina.skuodiene@lammc.lt \\ ${ }^{2}$ Lithuanian Research Centre for Agriculture and Forestry, Institute of Agriculture \\ Instituto 1, Akademija, Kèdainiai distr., Lithuania
}

\begin{abstract}
The study aimed to investigate changes in root development of grasslands in differently eroded ecotopes and impact on slope stability. The experiment was carried out at the Véžaičiai Branch of Lithuanian Research Centre for Agriculture and Forestry. The soil of the northern exposition slope was Bathygleyic Dystric Glossic Retisol (slightly eroded); the soil of the southern exposition slope, due to very severe erosion in the upper part, was Orthieutric Regosol (severely eroded). The impact of hill expositions (southern exposition, slope of $12-14^{\circ}$ and northern exposition, slope of $11-13^{\circ}$ ), parts of the hill (summit, midslope and footslope) and type of the grassland: temporary, established in 2014 (alfalfa (Medicago sativa L.) 50\% + timothy (Phleum pratense L.) 35\% + meadow grass (Poa pratensis L.) 15\%) and permanent, established in 1983 (timothy (Phleum pratense L.) 20\%, red fescue (Festuca rubra L.) 20\%, meadow grass (Poa pratensis L.) 20\%, white clover (Trifolium repens L.) 20\%, common bird's-foot trefoil (Lotus corniculatus L.) 20\%) on root development was very unequal. The root mass was significantly influenced by the age of the grasslands: in the $1^{\text {st }}$ experimental year the root mass of the permanent grassland was 13.4 times greater compared to that of the temporary grassland. Root mass differences gradually decreased, while temporary grassland developed and in the $3^{\text {rd }}$ year it levelled off. The highest proportion $(80-$ $90 \%$ ) of the investigated grassland root mass was found in $0-10 \mathrm{~cm}$ soil layer. Total root length of the temporary grassland was significantly greater on the footslope of the hill, and the average root diameter did not depend on the exposition and part of the hill. Hill slopes were not affected by water erosion, when sustainable agro-systems were based on growing perennial grassland and grass-cereal crop rotations with temporary grassland.
\end{abstract}

Key words: environmental conditions, grass ecosystems, morphological parameters of roots, slope stability.

\section{Introduction}

Soils play a vital role in the biodiversity and are the provider of numerous ecosystem services that support human life on Earth (Ronchi et al., 2019). Processes of the global climate change, resulting in damage to the environment, farming and development of the economy, are caused by intensive anthropogenic activity. Irresponsible agriculture leads to soil erosion, compaction, organic carbon decrease and decline in ecosystem biodiversity (Palm et al., 2014). Erosion caused damage can be characterised by the indicators, including degradation of the fertile soil layer, deterioration of physical and agrochemical soil properties, environmental pollution and soil productivity decrease (Feiza et al., 2008; Van Oost, Bakker, 2012; Vanmaercke et al., 2012; Panagos et al., 2018; Poesen, 2018; FAO, 2019).

The effect of vegetation on reducing soil erosion is well known. Plants intercept rainfall; some is stored in the canopy with the remainder evaporating or reaching the soil surface either directly as throughfall or indirectly through stem flow or leaf drainage (Puigdefábregas, 2005). Mixtures of different plant functional types improve soil conservation on slopes by reducing both surface water erosion and shallow substrate mass movement (Fattet et al., 2011). Perennial grassland is the main tool for reducing soil degradation. Perennial plants form a permanent soil cover, reducing the leaching of nutrients and erosion (Jarašiūnas, Kinderienè, 2016). Panagos et al. (2015) have estimated that the mean soil loss rate in the European Union's erosion-prone lands is $2.46 \mathrm{t} \mathrm{ha}^{-1} \mathrm{yr}^{-1}$. Soil erosion is the most intensive factor of Lithuanian relief transformation, given that the estimated volume of all deposits re-deposited by erosion reaches 47.6 million $\mathrm{m}^{3}$ sediments per year. The depth of denudation is greater than $0.5 \mathrm{~mm}^{-1} \mathrm{yr}^{-1}$ (Česnulevičius, 2011).

Soil erosion by water is a serious environmental problem representing a much greater threat to agricultural production than soil erosion by wind (Lal, 2010). According to Jarasiunas et al. (2017), Lithuanian

Please use the following format when citing the article:

Skuodienė R., Kinderienė I., Tomchuk D., Šlepetys J., Karčauskienė D. 2020. Root development of temporary and permanent grasslands and their anti-erosion significance on a hilly terrain. Zemdirbyste-Agriculture, 107 (3): 209-216. DOI 10.13080/z-a.2020.107.027 
agricultural land with unfavourable soil texture, poor soil drainage and steep slopes covers an area of 33.59, 4.76 and $1.03 \%$ of the total agricultural area, respectively. Lithuanian climate is favourable for the occurrence of water erosion (Jankauskas, 2012; Kinderiene, Karcauskiene, 2012). Data of the experiment in the Žemaičiai Highland showed that water erosion occurred under the grain-grass and grass-grain crop rotations at rates of 1.38 and $0.11 \mathrm{~m}^{3} \mathrm{ha}^{-1} \mathrm{yr}^{-1}$, respectively (Jarašiūnas, Kinderienè, 2016). Most favourable conditions for water erosion are in Western Lithuania (southwestern part of Žemaičiai Highland) with frequent thaws in winter and humid and cool weather in summer (Kinderiene, Karcauskiene, 2012). Climate warming processes (about $0.7^{\circ} \mathrm{C}$ over more than 30 years) Galvonaite et al. (2013), and a positive air temperature encourage snow melting and runoff water flow down the slope surface, even during the cold period (Kinderiene, Karčauskiene, 2016).

The use of vegetation to control erosion has long been a topic for research. Much of this research has focused on the above-ground properties of plants, demonstrating the important role that canopy structure and cover plays in the reduction of water erosion processes. Less attention has been paid to plant roots. Plant roots are a crucial yet under-researched factor for reducing water erosion through their ability to alter soil properties, such as aggregate stability, hydraulic function and shear strength (Ola et al., 2015). Nevertheless, the contribution of plant root systems to slope stability and soil erosion control has received a lot of attention in recent years.

The plant root system is an intricate and adaptive object, and understanding the details of soil and root interaction is a difficult but also very important task (Reubens et al., 2007). According to Gyssels et al. (2005), the decline in water erosion rates with expanding root mass is exponential. Roots serve as the major interface between the plant and various biotic and abiotic factors in the soil environment: by both sensing and responding to environmental cues, roots enable plants to overcome the challenges posed by their sessile status (Smith, De Smet, 2012). Given that grassland management practices can have anti-erosion importance, we hypothesise that temporary grasslands containing alfalfa will protect hill slopes from the water erosion like permanent grasslands do.

The aim of this study was to investigate changes in grassland root development in differently eroded ecotopes and impact on slope stability.

\section{Materials and methods}

Site and soil description and experimental design. The experiment was carried out at the Véžaičiai Branch of the Lithuanian Research Centre for Agriculture and Forestry on the midslope soil of Žemaičiai Highland covered by different anti-erosion agrophytocenoses (Kinderiené, Karčauskienė, 2016) in Kaltinènai during the period 20142016. Geographical location of the experiment: latitude $55^{\circ} 31^{\prime} \mathrm{N}$, longitude $22^{\circ} 30^{\prime} \mathrm{E}, 161.5 \mathrm{~m}$ a.s.l. The soil of the northern exposition slope was Bathygleyic Dystric Glossic Retisol (slightly eroded). The soil of the southern exposition slope, due to very severe erosion in the upper part, was Orthieutric Regosol (severely eroded). The soil in the middle and lower parts of the slope was the same as in the northern slope - Bathygleyic Dystric Glossic Retisol (slightly eroded) according to WRB (2014). The soil texture of the study sites was classified as sandy loam. Agrochemical and some physical properties of the arable $(0-20 \mathrm{~cm})$ soil layer at the beginning of the experiment are presented in Table 1.

The soil of temporary and permanent grasslands of different age varied in agrochemical and agrophysical properties. In the soil of temporary grassland, the amount of organic carbon was estimated to be significantly lower compared to permanent grassland. However, the soil in the plots of permanent grassland was more loosened compared to temporary grassland. Due to erosion and soil loss, Ap horizon in the summit of the southern exposition was very thin.

Factor A - hill exposition: 1) southern exposition, slope of $12-14^{\circ}, 2$ ) northern exposition, slope of $11-13^{\circ}$; factor B - parts of the hill: 1) summit, 2) midslope, 3) footslope; factor $\mathrm{C}$-type of the grassland: 1) temporary, 2) permanent.

The length of the northern slope was $90 \mathrm{~m}$ and that of the southern slope $-43 \mathrm{~m}$. Soil samples for analysis were collected from three replications of the summit, midslope and footslope of the hill. The slopes were divided into the parts according to the thickness of Ap horizon; the methodology is described in Jarašiūnas and Kinderienè (2016) study.

Soil management and fertiliser treatments were applied in accordance with the measured soil properties and standard regional agricultural practices. The main tillage, sowing, planting and harvesting directions were up-and-down the slope to decrease soil losses during intense rainfall. Grasslands were fertilised every year. The main fertilisation was done at the start of the growing season and the supplementary fertilisation was

Table 1. Agrochemical and physical properties of the arable $(0-20 \mathrm{~cm})$ soil layer in 2014

\begin{tabular}{|c|c|c|c|c|c|c|}
\hline \multirow{2}{*}{$\begin{array}{c}\text { Soil } \\
\text { properties }\end{array}$} & \multicolumn{3}{|c|}{ Temporary grassland } & \multicolumn{3}{|c|}{ Permanent grassland } \\
\hline & summit & midslope & footslope & summit & midslope & footslope \\
\hline \multicolumn{7}{|c|}{ Southern exposition } \\
\hline$\overline{\text { Acidity }\left(\mathrm{pH}_{\mathrm{KCl}}\right)}$ & $5.43 \pm 0.03$ & $5.67 \pm 0.05$ & $6.03 \pm 0.05$ & $5.93 \pm 0.08$ & $6.02 \pm 0.03$ & $6.02 \pm 0.03$ \\
\hline Mobile $\mathrm{P}_{2} \mathrm{O}_{5} \mathrm{mg} \mathrm{kg}^{-1}$ & $155.67 \pm 4.97$ & $141.00 \pm 9.99$ & $160.00 \pm 10.12$ & $130.67 \pm 12.26$ & $124.33 \pm 8.17$ & $106.67 \pm 11.40$ \\
\hline Mobile $\mathrm{K}_{2}^{2} \mathrm{O}^{5} \mathrm{mg} \mathrm{kg}^{-1}$ & $161.33 \pm 9.25$ & $150.17 \pm 2.09$ & $137.67 \pm 12.32$ & $81.33 \pm 4.37$ & $74.17 \pm 3.38$ & $59.83 \pm 2.32$ \\
\hline Organic C $\%$ & $0.91 \pm 0.01$ & $1.08 \pm 0.01$ & $1.10 \pm 0.05$ & $1.47 \pm 0.06$ & $1.36 \pm 0.02$ & $1.39 \pm 0.04$ \\
\hline Total N \% & $0.120 \pm 0.005$ & $0.111 \pm 0.004$ & $0.117 \pm 0.005$ & $0.127 \pm 0.002$ & $0.122 \pm 0.003$ & $0.127 \pm 0.003$ \\
\hline Bulk density $\mathrm{Mg} \mathrm{m}^{-3}$ & $1.57 \pm 0.03$ & $1.53 \pm 0.04$ & $1.44 \pm 0.05$ & $1.28 \pm 0.04$ & $1.02 \pm 0.02$ & $1.22 \pm 0.03$ \\
\hline Ap horizon thickness $\mathrm{cm}$ & $4.6 \pm 0.11$ & $21.5 \pm 0.93$ & $55.0 \pm 2.95$ & $8.8 \pm 0.43$ & $20.0 \pm 0.59$ & $39.7 \pm 1.67$ \\
\hline Moisture $^{1}$ & $15.0 \pm 0.88$ & $14.1 \pm 0.81$ & $14.0 \pm 0.86$ & $12.1 \pm 1.24$ & $13.9 \pm 1.25$ & $14.9 \pm 1.24$ \\
\hline \multicolumn{7}{|c|}{ Northern exposition } \\
\hline Acidity $\left(\mathrm{pH}_{\mathrm{KCl}}\right)$ & $5.98 \pm 0.01$ & $5.90 \pm 0.00$ & $5.98 \pm 0.03$ & $6.07 \pm 0.04$ & $5.97 \pm 0.10$ & $5.98 \pm 0.06$ \\
\hline Mobile $\mathrm{P}_{2} \mathrm{O}_{5} \mathrm{mg} \mathrm{kg}^{-1}$ & $198.83 \pm 8.69$ & $168.33 \pm 6.51$ & $163.00 \pm 7.91$ & $160.67 \pm 21.94$ & $153.67 \pm 38.41$ & $119.33 \pm 28.22$ \\
\hline Mobile $\mathrm{K}_{2}^{2} \mathrm{O}^{5} \mathrm{~m} \mathrm{~kg}^{-1}$ & $144.67 \pm 17.25$ & $121.00 \pm 4.92$ & $148.83 \pm 9.43$ & $91.17 \pm 2.85$ & $78.00 \pm 8.81$ & $80.33 \pm 8.24$ \\
\hline Organic C $\%$ & $1.23 \pm 0.17$ & $1.52 \pm 0.06$ & $1.58 \pm 0.05$ & $1.49 \pm 0.08$ & $1.52 \pm 0.20$ & $1.61 \pm 0.12$ \\
\hline Total N \% & $0.143 \pm 0.007$ & $0.151 \pm 0.010$ & $0.146 \pm 0.005$ & $0.142 \pm 0.003$ & $0.128 \pm 0.012$ & $0.145 \pm 0.007$ \\
\hline Bulk density $\mathrm{Mg} \mathrm{m}^{-3}$ & $1.56 \pm 0.03$ & $1.49 \pm 0.05$ & $1.46 \pm 0.07$ & $1.15 \pm 0.10$ & $1.13 \pm 0.02$ & $1.20 \pm 0.08$ \\
\hline Ap horizon thickness $\mathrm{cm}$ & $21.4 \pm 2.53$ & $18.8 \pm 0.59$ & $43.7 \pm 2.11$ & $25.3 \pm 2.17$ & $23.3 \pm 0.68$ & $46.3 \pm 2.26$ \\
\hline Moisture $^{1}$ & $15.8 \pm 0.77$ & $16.4 \pm 0.66$ & $17.0 \pm 0.61$ & $12.7 \pm 1.39$ & $13.9 \pm 1.25$ & $14.9 \pm 1.24$ \\
\hline
\end{tabular}

Note. ${ }^{1}$ - moisture is average soil moisture during the growing season in 2014; mean values \pm standard deviation. 
applied after mowing. Chemical fertiliser inputs were ammonium nitrate $\left(\mathrm{NH}_{4} \mathrm{NO}_{3}\right)$, granulated superphosphate and potassium chloride $(\mathrm{KCl})$.

Temporary grassland was grown in a grassgrain rotation including spring barley + perennial grasses (2014) $\rightarrow$ perennial grasses $(2015) \rightarrow$ perennial grasses (2016). Growing deep-rooted grasses on eroded soils is beneficial, therefore a mixture with alfalfa was chosen. Temporary grassland was composed of alfalfa (Medicago sativa L.) cultivar 'Birutè' at a seed rate of $12 \mathrm{~kg} \mathrm{ha}^{-1}+$ timothy (Phleum pratense L.) cultivar 'Dubingiai' at a seed rate of $10 \mathrm{~kg} \mathrm{ha}^{-1}+$ meadow grass (Poa pratensis L.) cultivar 'Rusne' at a seed rate of $10 \mathrm{~kg} \mathrm{ha}^{-1}$ (seed ratio in the mixture: $50 \%+35 \%+15 \%$, respectively).

The cover crop barley was fertilised with $\mathrm{N}_{60} \mathrm{P}_{60} \mathrm{~K}_{00}$ and sown on 17 April in 2014. The mixture of alfalfa and Poaceae grasses was sown on 18 April in 2014. In the $2^{\text {nd }}$ and $3^{\text {rd }}$ years of development $(2015$ 2016), the temporary grassland was fertilised with $\mathrm{P}_{60} \mathrm{~K}_{90}$. The temporary grassland was mown 2-3 times per year depending on the grass development. In the $2^{\text {nd }}$ year of development, temporary grassland was mown at the beginning of flowering of alfalfa (7 July, 2015, 20 August, 2015 and 23 October, 2015), in the $3^{\text {rd }}$ year of development, grassland was mown at the beginning of heading of Poaceae grasses (17 June, 12 August and 14 October, 2016)

Permanent grassland was sown in 1983 and has never been reseeded. Mixture of perennial grasses for the permanent grassland was: timothy (Phleum pratense L.) $20 \%$, red fescue (Festuca rubra L.) $20 \%$, meadow grass (Poa pratensis L.) 20\%, white clover (Trifolium repens L.) $20 \%$ and common bird's-foot trefoil (Lotus corniculatus L.) $20 \%$. Permanent grassland was fertilised with $\mathrm{N}_{90(60+30)} \mathrm{P}_{60} \mathrm{~K}_{90}$. The permanent grassland was mown 2-3 times a year, according to the stages of development of Poaceae grasses. In the $1^{\text {st }}$ year of the experiment, permanent grassland was mown on 16 June and 16 September in 2014, in the $2^{\text {nd }}$ year - on 07 July and 23 October in 2015, in the $3^{\text {rd }}$ year - on 17 June, 12 August and 14 October in 2016.

Soil sampling, chemical, physical and biological measurements. Soil samples for chemical analyses were collected from the $0-20 \mathrm{~cm}$ depth with a drill from each plot in the spring of 2014. Soil agrochemical characteristics were determined by the following methods: soil acidity - by the potentiometric method in the extraction of $1 \mathrm{M} \mathrm{KCl}\left(\mathrm{pH}_{\mathrm{KCl}}\right)$ according to ISO 10390:2005 (Soil quality - Determination of $\mathrm{pH}$ ); total nitrogen $\left(\mathrm{N}_{\text {tot }}\right)$ content - by the Kjeldahl method; mobile phosphorus $\left(\mathrm{P}_{2} \mathrm{O}_{5}\right)$ and potassium $\left(\mathrm{K}_{2} \mathrm{O}\right)$ in the soil using the Egner-Riehm-Domingo (A-L) method; organic carbon $\left(\mathrm{C}_{\mathrm{C}}\right)$ - by the dry combustion Dumas method.

Soil samples for physical analyses were collected from the $0-10$ and $10-20 \mathrm{~cm}$ depths from each plot, the soil bulk density was determined with a $100 \mathrm{~cm}^{3}$ cylindrical drill (by the Kachinsky method) in autumn.
Soil moisture content was evaluated every 2-3 weeks during the plant vegetation period in 2014-2016 and expressed on a dry weight basis after oven drying to a constant weight at $105^{\circ} \mathrm{C}$ temperature.

Samples of belowground phythomass (roots, excluding fully decomposed parts and residues) were collected and mass was determined in the autumn by the quantitative measuring method: the roots were dug in two places of each plot with a cylinder having an area of $78.5 \mathrm{~cm}^{2}$ from the $0-10$ and $10-20 \mathrm{~cm}$ soil layers, washed with running water through a $0.25 \mathrm{~mm}$ mesh with the best effort to retain fine roots, air-dried and weighed (Rosário et al., 2000). Plant roots were collected on 24 September in 2014, 20 October in 2015 and 17 October in 2016. The root diameter and the total root length of temporary grassland in 2014 and 2015 were determined from fresh material before drying using the Delta-T Scan Image Analysis System (Delta-T Devices Ltd., UK).

The dry matter yield of the grasslands was determined by weighing. To determine the percentage of dry matter in the herbage, fresh grass samples of $0.5 \mathrm{~kg}$ were collected from each plot and dried at a temperature of $105^{\circ} \mathrm{C}$.

Water erosion rates on agro-environmental stationary site were assessed by measuring the length and cross-sectional area of rills, to calculate soil loss volume $\left(\mathrm{m}^{3} \mathrm{ha}^{-1}\right)$ (Chambers et al., 2000; Jankauskas, Jankauskiene, 2003). The volume of soil loss by rill erosion was calculated using the formula:

$$
\mathrm{x}=\left[\left(\Sigma \mathrm{l}_{1} \mathrm{p}_{1}+\Sigma \mathrm{l}_{2} \mathrm{p}_{2}+\ldots \Sigma \mathrm{l}_{\mathrm{n}} \mathrm{p}_{\mathrm{n}}\right): \mathrm{n}\right]: \mathrm{y},
$$

where $\mathrm{x}$ is volume of rill erosion $\left(\mathrm{m}^{-3} \mathrm{ha}^{-1}\right) ; 1,1, \ldots$ $1_{n}$ - rill depth $\left(\mathrm{cm}^{-1}\right) ; \mathrm{p}, \mathrm{p}_{1}, \ldots \mathrm{p}_{\mathrm{n}}$ - rill width $\left(\mathrm{cm}^{-1}\right.$, accuracy $\left.\pm 0.1 \mathrm{~cm}^{-1}\right) ; \mathrm{n}$ - number of rills on the measured plot width; $\mathrm{y}-$ measured plot width $\left(\mathrm{m}^{-1}\right), \Sigma-$ sum of performed measurements from selected $1 \mathrm{~m}$ length segments located at equal distances on the experimental plot.

Weather conditions. During the vegetation period of 2014, the meteorological conditions for the growth of grasslands in Žemaičiai Highland were contrasting. After dry weather in April, the amount of rainfall in May and June was slightly higher than the standard climate norm $(\mathrm{SCN})$. The average air temperature was greater by $2.1^{\circ} \mathrm{C}$ and $0.3^{\circ} \mathrm{C}$ compared to the $\mathrm{SCN}$, and the soil moisture of the permanent grassland in May reached $8.3 \%$ in the southern exposition and $10.2 \%$ in the northern exposition (Fig. 1). The moisture content of temporary grassland soil was higher $(12.5 \%$ and $15.0 \%$, respectively) and was favourable for the development of temporary grassland. July was dry and hot with rainfall of only $73.1 \%$ of the $\mathrm{SCN}$, and the average monthly temperature of $19.4^{\circ} \mathrm{C}$, depleting the soil moisture reserves sharply in July, and in August, in the permanent grassland soil, reaching the soil moisture content close to the wilting point. At the end of the first ten-day period of August, with the abundance of rainfall (140.0\% of the SCN per month) soil moisture reserves were restored and became close to optimal.

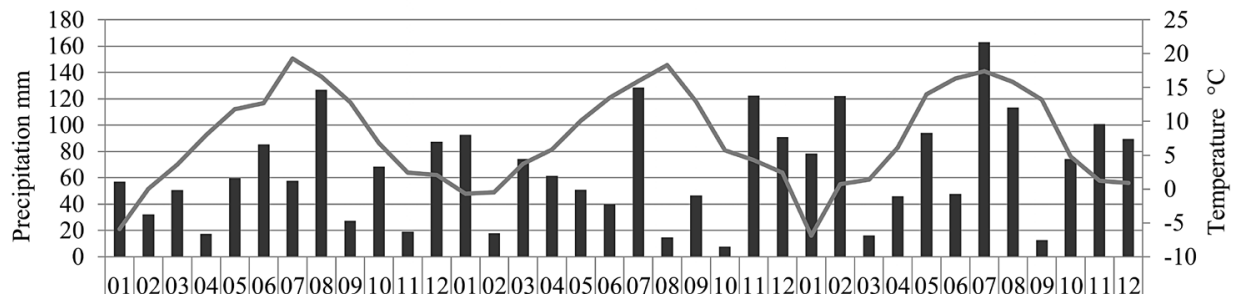

2014

2015

2016

- Precipitation $\quad$ Average air temperature

Figure 1. The precipitation and average air temperature during the experimental period (data from Laukuva Meteorological Station) 
September and October were dry and warm; soil moisture was sufficient $(12.5-19.9 \%)$. The vegetation period ended on the $29^{\text {th }}$ of October. In 2014, meteorological conditions were satisfactory for the growth of grasslands; the total amount of precipitation during the vegetation period reached $89.1 \%$ of the SCN.

In 2015, the plant vegetation period started on the $30^{\text {th }}$ of March. The distribution of precipitation during that period was uneven. In May the weather was wet and cool; the soil moisture content was optimal (15.4-23.7\%) for grasslands growth. However, very dry weather prevailed in June, August and October the amount of precipitation reached only 39,15 and 8 $\mathrm{mm}$. At the beginning of July, the moisture content of the soil was close to the wilting point and in the southern exposition of temporary grassland was only $7.1 \%$, while in the northern exposition $-9.0 \%$. In the permanent grassland, soil moisture content was $8.9 \%$ and $9.7 \%$, respectively. Abundant rain in July supplemented soil moisture reserves; however, in August and September, with unusually warm weather (the average temperature was greater by $2.1^{\circ} \mathrm{C}$ and $1.4^{\circ} \mathrm{C}$ than the $\mathrm{SCN}$ ), at the end of the vegetation period, soil moisture began to drop again. The vegetation period ended on the $19^{\text {th }}$ of October. The amount of precipitation during the vegetation period in 2015 distributed unevenly and reached only $70.9 \%$ of the SCN, which resulted in soil moisture level decrease at the beginning of July and October that was close to the wilting point. Meteorological conditions for grasslands in 2015 were only satisfactory.

In 2016, the plant vegetation began on the $6^{\text {th }}$ of April. In the first and third ten-day periods of May, the weather was dry and a small amount of rainfall was recorded in June with high average temperature and $10.1-13.8 \%$ decrease in the moisture content in the soil. After the abundant rain in July and August, the conditions for the growth of grasslands improved. September was dry and unusually warm, the amount of rainfall reached only $16.5 \%$ of the $\mathrm{SCN}$, and the average temperature was $13.2^{\circ} \mathrm{C}$, i.e. greater by $1.7^{\circ} \mathrm{C}$ compared to the $\mathrm{SCN}$. The vegetation period ended on the $17^{\text {th }}$ of October. In 2016, meteorological conditions were favourable for the growth of grasslands: the amount of precipitation in months of April-October exceeded the SCN by $11.3 \%$. Soil moisture conditions during the whole vegetation period were optimal.

Statistical analysis. The experimental data were statistically processed using the multi-factor analysis of variance (ANOVA) (Raudonius, 2017). The significance of the differences between the treatments was evaluated by the three-factor (root mass) and two-factor (dry matter yield, root length and diameter) analysis of variance. Significance of the differences between the means was determined according to the Fisher's protected least significant difference (LSD) at 0.05 probability level. The interdependences of individual characteristics were estimated by linear correlation coefficient $(r)$. The data of the soil chemical and physical parameters are presented as arithmetic mean and average square error of the mean with the software STAT, version 7.13 (SAS Institute Inc., USA).

\section{Results and discussion}

Root morphology. Roots are an integral part of plants, playing important functions in regulating whole-plant growth. The primary functions of roots are absorption of water and other nutrients from the soil and anchor the plant (Gregory, 2008). Analysis of variance revealed significant influence of grassland type (factor C) on the examined indicators of root morphological parameters. A significant impact of hill exposition (factor
A) and part of the hill (factor B) on the total root length was determined.

In the $1^{\text {st }}$ year of the experiment, in the southern exposition of temporary grassland, the lowest root mass was estimated on the summit of the hill due to the lack of moisture in the eroded soil. The highest root mass was estimated to be on the footslope of the hill, which was more favourable for plant growth (Table 2). Due to the thick humus soil layer formed in the northern exposition at the summit and midslope of the hill, temporary grassland produced by $46.7 \%$ and $70.9 \%$ bigger root mass, and on the footslope it was lower by $54.3 \%$ compared to the southern exposition.

The data of the experiment show that in the $1^{\text {st }}$ year of development, the average root diameter of temporary grassland did not depend on the hill exposition and part of the hill; the differences were not significant. The root diameter was greater at $0-10 \mathrm{~cm}$ depth, respectively: $37.2-42.2 \%$ in the southern exposition and $22.5-84.0 \%$ in the northern exposition, compared to that at the depth of 10-20 cm (Table 3).

Due to different pedoclimatic factors, hill exposition and part of the hill influenced the total root length. The total root length in the northern exposition was $26.1 \%$ greater compared to the southern exposition. Irrespective of the exposition, the total root length at both (0-10 and 10-20 cm) depths was determined to be significantly greater on the footslope of the hill compared to the summit. The total root length in grassland ecosystems gives the information about root distribution in the soil; longer roots positively affect the stability of soil aggregates (Ola et al., 2015) thus protecting the soil from erosion.

In the $2^{\text {nd }}$ year of temporary grassland development, root mass was 2.5-11.1 times greater compared to the $1^{\text {st }}$ year. The lowest root mass of the grassland was determined in the southern exposition (like in the $1^{\text {st }}$ year of grassland development), while the highest root mass - on the footslope of the northern exposition. However, the root diameter in all experimental plots was smaller by $8.5-22.9 \%$ and $17.5-31.5 \%$, respectively, in the southern exposition and in the northern exposition compared to the $1^{\text {st }}$ year of grassland development. Smaller root diameter might have resulted from the lack of moisture in the soil during the vegetation period. Significantly lowest root diameter was determined on the footslope of the hill at the depth of 10-20 cm (Table 3). It is likely that plants formed a bigger amount of small roots thus expanding their surface area for more effective uptake of moisture and nutrients.

In the $2^{\text {nd }}$ year of temporary grassland development, the total root length was 2.1 times greater compared to the $1^{\text {st }}$ year and was significantly influenced by the hill exposition and part of the hill. In the northern exposition at $0-10 \mathrm{~cm}$ depth, the total root length was greater by $39.5 \%$ and at $10-20 \mathrm{~cm}$ depth it was greater by $33.3 \%$ compared to the southern exposition. Irrespective of the exposition, the total root length on the footslope of the hill was significantly greater compared to the other parts of the hill.

The root length in temporary grassland of the $2^{\text {nd }}$ year of age depended on soil moisture: medium strong correlation was determined at $0-10 \mathrm{~cm}$ depth $\left(r=0.553^{*}\right)$ and weak correlation - at $10-20 \mathrm{~cm}$ depth $\left(r=0.476^{*}\right)$. The difference in root distribution is a factor influencing the extent to which plants are able to tolerate moisture stress, but it may also have beneficial effects on soil porosity delivering ecosystem services (Marshall et al., 2014).

In the $3^{\text {rd }}$ year of temporary grassland development, when the grassland was fully formed, the root mass was by on average $49 \%$ higher than in the $2^{\text {nd }}$ year of grassland development. The highest root mass 
Table 2. The impact of hilly terrain on the changes in root mass $\left(\mathrm{g} \mathrm{m}^{-2}\right)$ of the temporary and permanent grasslands

\begin{tabular}{|c|c|c|c|c|c|c|}
\hline \multirow{2}{*}{ Treatment } & \multicolumn{2}{|c|}{2014} & \multicolumn{2}{|c|}{2015} & \multicolumn{2}{|c|}{2016} \\
\hline & $0-10 \mathrm{~cm}$ & $10-20 \mathrm{~cm}$ & $0-10 \mathrm{~cm}$ & $10-20 \mathrm{~cm}$ & $0-10 \mathrm{~cm}$ & $10-20 \mathrm{~cm}$ \\
\hline \multicolumn{7}{|c|}{ Hill exposition (factor A) } \\
\hline 1. Southern exposition & 654.92 & 61.54 & 831.42 & 55.77 & 749.89 & 116.21 \\
\hline 2. Northern exposition & 695.12 & 44.48 & 809.98 & 62.10 & 871.37 & 102.05 \\
\hline $\mathrm{LSD}_{05}$ & 267.723 & 18.597 & 189.236 & 26.632 & 195.766 & 55.211 \\
\hline \multicolumn{7}{|c|}{ Part of the hill (factor B) } \\
\hline 1. Summit & 749.84 & 39.28 & 801.27 & 79.67 & 833.60 & 133.60 \\
\hline 2. Midslope & 600.80 & 56.26 & 830.36 & 50.42 & 856.90 & 121.82 \\
\hline 3. Footslope & 674.42 & $63.48 *$ & 830.47 & $46.71 *$ & 741.40 & 71.97 \\
\hline $\mathrm{LSD}_{05}$ & 327.893 & 22.777 & 231.766 & 32.617 & 239.763 & 67.620 \\
\hline \multicolumn{7}{|c|}{ Grassland type (factor C) } \\
\hline 1.Temporary grassland & 93.52 & 11.46 & 538.85 & 55.17 & 736.20 & 148.55 \\
\hline 2. Permanent grassland & $1256.51 * *$ & $94.55 * *$ & $1102.55 * *$ & 62.70 & 885.07 & $69.71 * *$ \\
\hline $\mathrm{LSD}_{05}$ & 267.723 & 18.597 & 189.236 & 26.632 & 195.766 & 55.211 \\
\hline \multicolumn{7}{|c|}{ Interaction of factors $\mathrm{A}, \mathrm{B}$ and $\mathrm{C}$} \\
\hline $\mathrm{A} 1 \times \mathrm{B} 1 \times \mathrm{C} 1$ & 60.08 & 7.22 & 480.04 & 114.44 & 853.72 & 172.61 \\
\hline $\mathrm{A} 1 \times \mathrm{B} 1 \times \mathrm{C} 2$ & $1403.82 * *$ & $90.23 * *$ & $1126.11 * *$ & 62.63 & 837.37 & 106.16 \\
\hline $\mathrm{A} 1 \times \mathrm{B} 2 \times \mathrm{C} 1$ & 76.22 & 10.62 & 667.73 & 53.93 & 805.10 & 208.07 \\
\hline $\mathrm{A} 1 \times \mathrm{B} 2 \times \mathrm{C} 2$ & $984.71 * *$ & $111.25 * *$ & $966.88 *$ & $42.68 *$ & 819.75 & 60.51 \\
\hline $\mathrm{A} 1 \times \mathrm{B} 3 \times \mathrm{C} 1$ & 137.79 & 19.11 & 607.43 & $20.59 * *$ & 436.73 & 75.80 \\
\hline $\mathrm{A} 1 \times \mathrm{B} 3 \times \mathrm{C} 2$ & $1266.88 * *$ & $130.79 * *$ & $1140.34 * *$ & $40.34 *$ & 746.71 & 74.10 \\
\hline $\mathrm{A} 2 \times \mathrm{B} 1 \times \mathrm{C} 1$ & 92.57 & 6.16 & 388.75 & 67.94 & 763.69 & 186.20 \\
\hline $\mathrm{A} 2 \times \mathrm{B} 1 \times \mathrm{C} 2$ & $1442.89 * *$ & $53.50 *$ & $1210.19 * *$ & 73.67 & 879.62 & 69.43 \\
\hline $\mathrm{A} 2 \times \mathrm{B} 2 \times \mathrm{C} 1$ & 131.21 & 17.20 & 352.02 & $15.29 * *$ & 876.01 & 150.74 \\
\hline $\mathrm{A} 2 \times \mathrm{B} 2 \times \mathrm{C} 2$ & $1211.04 * *$ & $85.99 * *$ & $1334.82 *$ & 89.81 & 926.75 & 67.94 \\
\hline $\mathrm{A} 2 \times \mathrm{B} 3 \times \mathrm{C} 1$ & 63.27 & 8.49 & 737.15 & 58.81 & 681.95 & 97.88 \\
\hline $\mathrm{A} 2 \times \mathrm{B} 3 \times \mathrm{C} 2$ & $1229.72 * *$ & $95.54 * *$ & 836.94 & 67.09 & 1100.21 & 40.13 \\
\hline $\mathrm{LSD}_{05}$ & 655.785 & 45.554 & 463.532 & 65.235 & 479.526 & 135.240 \\
\hline \multicolumn{7}{|c|}{ Significance according to $F$-test } \\
\hline Factor A & ns & ns & ns & ns & ns & ns \\
\hline Factor B & ns & ns & ns & ns & ns & ns \\
\hline Factor C & $* *$ & $* *$ & $* *$ & ns & ns & $* *$ \\
\hline $\mathrm{A} \times \mathrm{B} \times \mathrm{C}$ & ns & ns & ns & ns & ns & ns \\
\hline
\end{tabular}

* and ** - significant at 0.05 and 0.01 level, $\mathrm{LSD}_{05}$ - the least significant difference, $\mathrm{ns}$ - not significant

Table 3. The impact of hilly terrain on root diameter and total root length of the temporary grassland

\begin{tabular}{|c|c|c|c|c|c|c|c|c|}
\hline \multirow{3}{*}{ Treatment } & \multicolumn{4}{|c|}{ Root diameter $\mathrm{mm}$} & \multicolumn{4}{|c|}{ Total root length $\mathrm{km} \mathrm{m}^{-2}$} \\
\hline & \multicolumn{2}{|c|}{2014} & \multicolumn{2}{|c|}{2015} & \multicolumn{2}{|c|}{2014} & \multicolumn{2}{|c|}{2015} \\
\hline & $0-10 \mathrm{~cm}$ & $10-20 \mathrm{~cm}$ & $0-10 \mathrm{~cm}$ & $10-20 \mathrm{~cm}$ & $0-10 \mathrm{~cm}$ & $10-20 \mathrm{~cm}$ & $0-10 \mathrm{~cm}$ & $10-20 \mathrm{~cm}$ \\
\hline \multicolumn{9}{|c|}{ Hill exposition (factor A) } \\
\hline $\begin{array}{l}\text { 1. Southern exposition } \\
\text { 2. Northern exposition }\end{array}$ & $\begin{array}{l}1.081 \\
1.65\end{array}$ & $\begin{array}{l}0.777 \\
0.09\end{array}$ & $\begin{array}{l}0.893 \\
0.822\end{array}$ & $\begin{array}{l}0.683 \\
0.619\end{array}$ & $\begin{array}{l}0.354 \\
0.436^{*} \\
\end{array}$ & $\begin{array}{l}0.133 \\
0.178 * \\
\end{array}$ & $\begin{array}{l}0.757 \\
1.056^{*}\end{array}$ & $\begin{array}{c}0.219 \\
0.292 * \\
\end{array}$ \\
\hline $\mathrm{LSD}_{05}$ & 0.1550 & 0.1580 & 0.1220 & 0.1130 & 0.0650 & 0.0430 & 0.2540 & 0.0650 \\
\hline \multicolumn{9}{|c|}{ Part of the hill (factor B) } \\
\hline 1. Summit & $\begin{array}{l}1.159 \\
1071\end{array}$ & $\begin{array}{l}0.722 \\
0.790\end{array}$ & $\begin{array}{l}0.801 \\
0.934\end{array}$ & 0.773 \% & 0.280 & 0.103 & $\begin{array}{l}0.670 \\
0.592\end{array}$ & 0.227 \\
\hline 3. Footslope & 1.139 & 0.867 & 0.836 & $0.577 * *$ & $0.473 * *$ & $0.221 * *$ & $1.456 * *$ & $0.326^{*}$ \\
\hline $\mathrm{LSD}_{05}$ & 0.1895 & 0.1939 & 0.1489 & 0.1386 & 0.0792 & 0.0526 & 0.3115 & 0.0798 \\
\hline \multicolumn{9}{|c|}{ Interaction of factors A and B } \\
\hline $\mathrm{A} 1 \times \mathrm{B} 1$ & 0.998 & 0.727 & 0.769 & 0.822 & 0.226 & 0.090 & 0.702 & 0.187 \\
\hline $\mathrm{A} 1 \times \mathrm{B} 2$ & 1.130 & 0.821 & $1.034 *$ & 0.641 & $\begin{array}{l}0.351 * \\
0.484 * *\end{array}$ & $0.098 *$ & 0.474 & 0.207 \\
\hline $\mathrm{A} 2 \times \mathrm{B} 1$ & $1.319^{*}$ & 0.717 & 0.834 & 0.723 & 0.334 & 0.116 & 0.638 & 0.268 \\
\hline $\begin{array}{l}\mathrm{A} 2 \times \mathrm{B} 2 \\
\mathrm{~A} 2 \times \mathrm{B} 3\end{array}$ & 1.012 & 0.760 & 0.835 & $0.565 \%$ & $0.511 * *$ & $0.188 *$ & 0.711 & 0.220 \\
\hline $\mathrm{LSD}_{05}$ & 0.2680 & 0.2740 & 0.2110 & 0.1960 & 0.1120 & 0.0740 & 0.4410 & 0.1130 \\
\hline \multicolumn{9}{|c|}{ Significance according to $F$-test } \\
\hline Factor A & ns & ns & ns & ns & $*$ & $*$ & $*$ & $*$ \\
\hline $\begin{array}{r}\text { Factor B } \\
\text { Interaction A }\end{array}$ & ns & ns & ns & & $* *$ & $* *$ & $\begin{array}{c}* * \\
*\end{array}$ & * \\
\hline Interaction $\mathrm{A}$ & ns & ns & ns & ns & ns & ns & * & ns \\
\hline
\end{tabular}

* and ** - significant at 0.05 and 0.01 level, $\mathrm{LSD}_{05}$ - the least significant difference, $\mathrm{ns}$ - not significant

was found at the summit and midslope of the hill in the southern and northern expositions.

The root mass distribution of the temporary grassland in different soil depths during the $1^{\text {st }}$ and the $2^{\text {nd }}$ year of development was similar: on average $88 \%$ of the total root mass was accumulated at $0-10 \mathrm{~cm}$ depth and about $12 \%$ - at $10-20 \mathrm{~cm}$ depth. In the $3^{\text {rd }}$ year of grassland age, the root mass that had accumulated at 10$20 \mathrm{~cm}$ depth increased by $20 \%$.

The root mass of the permanent grassland during the experimental years varied from 820.8 to $1494.0 \mathrm{~g} \mathrm{~m}^{-2}$ in the arable (total $0-10$ and $10-20 \mathrm{~cm}$ ) soil layers (Table 2). The root mass accumulated at $10-20 \mathrm{~cm}$ depth amounted to an average $7.0 \%$ and did not change over the three experimental years. It is believed that over more than 30 years, a distinctive microecosystem with no big changes had formed in the permanent grassland. As a result, the differences of the root mass were determined to be minor. Irrespective of the hill exposition and part of the hill in the $1^{\text {st }}$ year of the experiment, the root mass in the permanent grassland was determined to be significantly greater at $0-10$ and $10-20 \mathrm{~cm}$ depths compared to the temporary grassland, whose root system development had begun recently. In the $1^{\text {st }}$ experimental year, the root mass of the permanent grassland was 13.4 times greater compared to the temporary grassland. 
In the $2^{\text {nd }}$ year of the experiment, the root mass of permanent grassland was significantly greater only at $0-10 \mathrm{~cm}$ depth compared to the temporary grassland. In the $3^{\text {rd }}$ year of the experiment, the root mass of permanent and temporary grasslands was similar, no significant differences were determined. This shows that the root system of temporary grassland was completely developed in the $3^{\text {rd }}$ year of age. The highest proportion $(80-90 \%)$ of the investigated grass root mass was found at $0-10 \mathrm{~cm}$ soil layer.

The yield of temporary grasslands. In the $2^{\text {nd }}$ year of grasslands development, the amount of precipitation during the vegetation period was lower by $29 \%$ compared to the SCN. Therefore, due to more favourable soil moisture content in the northern exposition, temporary grasslands produced significantly or $83.4 \%$ greater dry matter (DM) yield than in the southern exposition (Fig. 2). The greatest dry matter yield was produced in temporary grassland at the summit of the hill in the northern exposition.

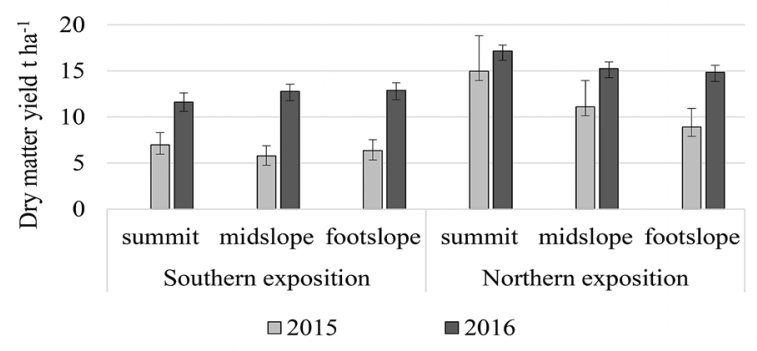

Note. Error bars denote standard deviations.

Figure 2. Dry matter yield of temporary grasslands in the $2^{\text {nd }}$ and $3^{\text {rd }}$ year of the experiment

In the $3^{\text {rd }}$ year of temporary grasslands development, dry matter yield was determined to be greater by $55.3 \%$ compared to the $2^{\text {nd }}$ year of grassland age. This was influenced by the development of alfalfa and favourable meteorological conditions as well. The correlation analysis showed moderately strong dry matter yield relationship $\left(r=0.573^{*}\right)$ of temporary grassland with the average soil moisture content during the vegetation period. In the northern exposition, dry matter yield of the temporary grassland was determined to be greater by $27.0 \%$ compared to the southern exposition. Dry matter yield varied slightly among different parts of the hill in both expositions: it was estimated to be greater in the northern exposition at the summit of the hill and in the southern exposition - at the footslope.

The yield of permanent grasslands. In the $1^{\text {st }}$ year of the experiment, dry matter yield of the permanent grassland at the summit and footslope of the hill in the southern exposition was 2.6 times lower compared to the same parts of the hill in the northern exposition (Fig. 3). Due to different pedoclimatic factors, irrespective of the exposition, significantly greatest dry matter yield was determined at footslope of the hill.

In the $2^{\text {nd }}$ year of the experiment, due to smaller amount of precipitation during the vegetation period, dry matter yield was 2.4 and 1.8 times lower in the southern and northern expositions, respectively. However, comparing grassland productivity in different parts of the hill the same tendencies remained. The correlation analysis showed moderately strong relationship $(r=$ $0.688^{* *}$ ) of the permanent grassland dry matter yield with the average soil moisture content during the vegetation period. In the $3^{\text {rd }}$ year of the experiment, soil moisture for the grassland development was sufficient, therefore dry matter yield was determined to be 1.9-2.9 times greater compared to the $2^{\text {nd }}$ year of the experiment. In the northern

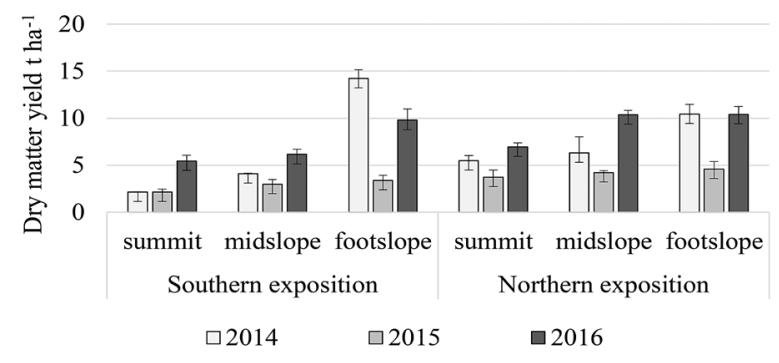

Note. Error bars denote standard deviations.

Figure 3. Dry matter yield of permanent grassland in the experimental years

exposition, as through all investigation years, dry matter yield was greater compared to the southern exposition. The correlation analysis showed moderately strong dry matter yield relationship $(r=0.633 * *)$ of permanent grassland with the average soil moisture content during the vegetation period.

Effect of grasses on soil erosion processes on slopes. In most European countries, scientists are interested in soil erosion controlling factors and mechanisms of landscape forming processes, such as slope or hill wash. The authors note that the vegetal cover in the natural plot reduced the energy available for erosion from the rainfall by $50 \%$, and, the energy from the runoff by $75 \%$, hindering the breakdown of aggregates and the transport of dense particles (Martinez-Mena et al., 2000). Plants that produce a rich root system strengthen and protect the soil surface from erosion. Long-term, constantly regenerating plants that are located to protect slopes from erosion should be considered for reducing the energy of raindrops during heavy rains. Plant cover protects soil against erosion by reducing water runoff and by increasing water infiltration into the soil matrix (Wainwright et al., 2002).

According to long-term results, due to firm soil surface formation and coverage with sod of grasses on the slope, this permanent grassland was a constant antierosion protection of slope soil (for over 30 years). In this situation, grass vegetation was as physical and biological barrier for the water runoff from the slope surface. Over the study time, soil erosion processes did not occur on steep slopes, permanently occupied with perennial grasses mixture.

The data of the present study show that soil erosion processes can be reduced by grass-crop rotation (by $89.3 \%$ ) and stabilised by multi-component grass mixtures (by $99.3-100.0 \%$ ) of permanent grassland. Moreover, these methods can reduce the rainfall outflow by $46 \%$ and $57 \%$, respectively. Soil water erosion processes did not occur over the 2014-2016 period. Perennial grasses completely prevented slopes from water erosion, because on average $88 \%$ of the total root mass was accumulated on the soil surface at $0-10 \mathrm{~cm}$ depth.

Results in Table 4 revealed the strong decrease of soil loss, when applying anti-erosion land-use systems with formed vegetation cover of permanent and temporary plants. Due to the abundance of roots of perennial grasses, the grass-grain crop rotation systems as well as fertilised and mown permanent grassland decreased soil erodibility and thus could assist erosion control and the ecological stability of the hilly-undulating landscape.

It is very important to form agrophytocenosis, which would be productive on hilly terrain and could protect the soil from erosion effectively (Jankauskas, 2012). Perennial grasses are the most reliable means protecting the soil from erosion (Jarašiūnas, Kinderienè, 2016). It is essential to plant over $10^{\circ}$ slopes with mixtures of perennial grasses, compact the soil by agricultural 
Table 4. Indicators of soil erosion processes of slope soil using different land-use systems

\begin{tabular}{|c|c|c|c|}
\hline \multirow{2}{*}{ Land-use system } & $\begin{array}{c}\text { Runoff } \\
\text { coefficient }^{1}\end{array}$ & $\begin{array}{l}\text { Soil loss reduction effectiveness } \\
(\text { SLRE })^{1}\end{array}$ & $\begin{array}{c}\text { Soil erosion losses } \\
\mathrm{m}^{3} \mathrm{ha}^{-1}\end{array}$ \\
\hline & $1995-2012$ & $1995-2012$ & $2014-2016$ \\
\hline Grass-grain crop rotation (temporary grassland) & 0.54 & 89.3 & 0.0 \\
\hline Fertilised and mown (permanent grassland) & 0.43 & 99.3 & 0.0 \\
\hline
\end{tabular}

${ }^{1}$ - according to Kinderienè and Karčauskienè (2016)

machinery if possible and also introduce anti-erosion field rotations including perennials. Temporary grassland with alfalfa is fertile and longevous, and the relatively greater amount of underground phytomass (compared to other plants) essentially reduces erosion (Wu et al., 2011).

Multi-species agro-ecosystems as sod-forming long term perennial grasses and plants of grassgrain crop rotations are potential components for soil conservation strategies on undulating relief (Jankauskas et al., 2008). Permanent grassland completely stopped soil erosion effects, therefore geomorphologic change and degradation of hills was estimated there as minimal (Jarašiūnas, Kinderienè, 2016). In areas with high erosion risk, land abandonment is followed by natural vegetation regeneration, resulting in decreased soil erosion.

Estimating anti-erosion characteristics of the grassland, root morphology is one of the most important elements for the research (Stokes, 2009; Ola et al., 2015). Root diameter is an indicator of root longevity, strength and ability to penetrate deeper layers of the soil (Clark et al., 2008); it can also determine plant ability to transport and accumulate water (Roumet et al., 2006). Thicker roots fixate in soil of the grassland and after the sward is formed, slopes of the hill are protected from the running water flows (Stokes, 2009).

\section{Conclusions}

1. Grassland age, exposition and part of the hill as well as environmental conditions had an impact on dry matter (DM) yield of the grassland. In the $2^{\text {nd }}$ and the $3^{\text {rd }}$ year of grassland development, due to more favourable soil moisture conditions, temporary grasslands produced significantly greater yield in the northern exposition compared to the southern exposition, respectively $83.4 \%$ and $27.0 \%$. During all experimental period, dry matter yield of the permanent grassland was greater in the northern exposition.

2. The root development and growth of temporary and permanent grasslands significantly depended on the grassland age: in the $1^{\text {st }}$ year, at a soil depth of $0-20 \mathrm{~cm}$ the already formed permanent grassland accumulated 13.4 times, and in the $2^{\text {nd }}$ year -2 times greater root mass than the temporary grassland. In the $3^{\text {rd }}$ year of age, the root system of temporary grassland was fully developed and was similar to that of permanent grassland. The total root length of the temporary grassland due to the thick humus layer was significantly greater at the footslope of the hill. The average root diameter of temporary grassland did not depend on the exposition and part of the hill.

3 . Hill slopes were not affected by water erosion. Temporary and perennial grasslands form a permanent soil cover and improve soil conservation on slopes.

\section{Acknowledgements}

The paper presents experimental findings, obtained through the long-term research programme "Productivity and sustainability of agricultural and forest soils" implemented by Lithuanian Research Centre for Agriculture and Forestry.

Received 24092019

Accepted 25032020

\section{References}

1. Chambers B. J., Garwood T. W. D., Unwin R. J. 2000 Controlling soil water erosion and phosphorus losses from arable land in England and Wales. Journal of Environmental Quality, 29 (1): 145-150.

https://doi.org/10.2134/jeq2000.00472425002900010018x

2. Česnulevičius A. 2011. The morphometric structure of Lithuanian relief and its influence on erosion processes. Baltica. Geosciences in Lithuania: challenges and perspectives (spec. iss.), 24: 137-142 (in Lithuanian).

3. Clark L. J., Price A. H., Steele K. A., Whalley W. R. 2008. Evidence from near-isogenic lines that root penetration increases with root diameter and bending stiffness in rice. Functional Plant Biology, 35 (11): 1163-1171. https://doi.org/10.1071/FP08132

4. FAO. 2019. Soil erosion: the greatest challenge to sustainable soil management, $100 \mathrm{p}$.

5. Fattet M., Fu Y., Ghestem M., Ma W., Foulonneau M. Nespoulous J., Le Bissonnais Y., Stokes A. 2011. Effects of vegetation type on soil resistance to erosion: relationship between aggregate stability and shear strength. Catena, 87 (1): 60-69. https://doi.org/10.1016/j.catena.2011.05.006

6. Feiza V., Feizienè D., Jankauskas B., Jankauskienè G. 2008. The impact of soil management on surface runoff, soil organic matter content and soil hydrological properties on the undulating landscape of Western Lithuania. Zemdirbyste-Agriculture, 95 (1): 3-21.

https://doi.org/10.13080/z-a.2015.102.001

7. Galvonaite A. Kilpys J., Kitrienè Z., Valiukas D. 2013. Climate averages for Lithuania 1981-2010, p. 2-8 (in Lithuanian).

8. Gyssels G., Poesen J., Bochet E., Li Y. 2005. Impact of plant roots on the resistance of soils to erosion by water: a review. Progress in Physical Geography, 29 (2): 189-217. https://doi.org/10.1191/0309133305pp443ra

9. Gregory P. J. 2008. Plant roots: growth, activity and interactions with the soil. Wiley-Blackwell, $328 \mathrm{p}$.

10. Jankauskas B. 2012. Soil erosion: case study, Lithuania Jakobsson C. (ed.). Sustainable agriculture. Ecosystem health and sustainable agriculture. Uppsala, Sweden, p. 231-238.

11. Jankauskas B., Jankauskienè. G. 2003. Erosion-preventive crop rotations for landscape ecological stability in upland regions of Lithuania. Agriculture, Ecosystems and Environment, 95 (1): 129-142.

https://doi.org/10.1016/S0167-8809(02)00100-7

12. Jankauskas B., Jankauskiene G., Fullen M. A. 2008. Soil erosion and changes in the physical properties of Lithuanian Eutric Albeluvisols under different land use systems. Acta Agriculturae Scandinavica, Section B: Soil and Plant Science, 58 (1): 66-76. https://doi.org/10.1080/09064710701214379

13. Jarasiunas G., Kinderiene I., Bašić F. 2017. Delineation Lithuanian agricultural land for agro-ecological suitability for farming using soil and terrain criteria. Ekológia (Bratislava), 36 (1): 95-106. https://doi.org/10.1515/eko-2017-0008

14. Jarašiūnas G., Kinderienè I. 2016. Impact of agroenvironmental systems on soil erosion processes and soil properties on hilly landscape in Western Lithuania. Journal of Environmental Engineering and Landscape Management, 24 (1): 60-69. https://doi.org/10.3846/16486897.2015.1054289

15. Kinderiene I., Karcauskiene D. 2012. Effects of different crop rotations on soil erosion and nutrient losses under natural rainfall conditions in Western Lithuania. Acta Agriculturae Scandinavica, Section B: Soil and Plant Science, 62 (2): 199-205.

https://doi.org/10.1080/09064710.2012.714400

16. Kinderienè I., Karčauskienė D. 2016. Assessment of soil erosion processes as influenced by different land-use systems on hilly rolling landscape of Western Lithuania. Zemdirbyste-Agriculture, 103 (4): 339-346. https://doi.org/10.13080/z-a.2016.103.043 
17. Lal R. 2010. Managing soils for a warming earth in a food-insecure and energy-starved world. Journal of Plant Nutrition and Soil Science, 173: 4-15. https://doi.org/10.1002/jpln.200900290

18. Marshall A. H., Lowe M., Sizer-Coverdale E. 2014. Root architecture of interspecific hybrids between Trifolium repens L. and Trifolium ambiguum M. Bieb. and their potential to deliver ecosystem services. Grassland Science in Europe, 19: 350-352.

19. Martinez-Mena M., Alvarez Rogel J., Albaladejo J., Castillo V. M. 2000. Influence of vegetal cover on sediment particle size distribution in natural rainfall conditions in a semiarid environment. Catena, 38 (3): 175-190. https://doi.org/10.1016/S0341-8162(99)00073-9

20. Ola A., Dodd I. C., Quinton J. N. 2015. Can we manipulate root system architecture to control soil erosion? Soil, 1: 603-612. https://doi.org/10.5194/soil-1-603-2015

21. Palm C., Blanco-Canqui H., DeClerck F., Gatere L., Grace P. 2014. Conservation agriculture and ecosystem services: an overview. Agriculture, Ecosystems and Environment, 187: 87-105. https://doi.org/10.1016/j.agee.2013.10.010

22. Panagos P., Borrelli P., Poesen J., Ballabio C., Lugato E., Meusburger K., Montanarella L., Alewel C. 2015. The new assessment of soil loss by water erosion in Europe. Environmental Science and Policy, 54: 438-447. https://doi.org/10.1016/i.envsci.2015.08.012

23. Panagos P., Standardi G., Borrelli P., Lugato E. Montanarella L., Bosello F. 2018. Cost of agricultural productivity loss due to soil erosion in the European Union: from direct cost evaluation approaches to the use of macroeconomic models. Land Degradation and Development, 29: 471-484. https://doi.org/10.1002/ldr.2879

24. Poesen J. 2018. Soil erosion in the Anthropocene: research needs. Earth Surface Processes and Landforms, 43 (1): 64-84. https://doi.org/10.1002/esp.4250

25. Puigdefábregas J. 2005. The role of vegetation patterns in structuring runoff and sediment fluxes in drylands. Earth Surface Processes and Landforms, 30: 133-147. https://doi.org/10.1002/esp.1181

26. Reubens R., Poesen J., Danjon F., Geudens G., Muys B. 2007. The role of fine coarse roots in shallow slope stability and soil erosion control with a focus on root system architecture: a review. Trees. Structure and Function, 21 (4): 385-402. https://doi.org/10.1007/s00468-007-0132-4

27. Raudonius S. 2017. Application of statistics in plant and crop research: important issues. Zemdirbyste-Agriculture, 104 (4): 377-382. https://doi.org/10.13080/z-a.2017.104.048
28. Ronchi S., Salata S., Arcidiacono A., Piroli E., Montanarella L. 2019. Policy instruments for soil protection among the EU member states: a comparative analysis. Land Use Policy, 82: 763-780. https://doi.org/10.1016/j.landusepol.2019.01.017

29. Rosário M. G. O., van Noordwijk M., Gaze S. R., Brouwer G., Bona S., Mosca G., Hairiah K. 2000. Chapter 6. Auger sampling, ingrowth cores and pinboard methods. Smit A. L. et al. (eds). Root methods. A handbook. Springer, p. 175210. https://doi.org/10.1007/978-3-662-04188-8 6

30. Roumet C., Urcelay C., Díaz S. 2006. Suites of root traits differ between annual and perennial species growing in the field. New Phytologist, 170: 357-368.

https://doi.org/10.1111/j.1469-8137.2006.01667.x

31. Smith S., De Smet I. 2012. Root system architecture: insights from Arabidopsis and cereal crops. Philosophical Transactions of the Royal Society B: Biological Sciences, 367 (1595): 1441-1452.

https://doi.org/10.1098/rstb.2011.0234

32. Stokes A. 2009. Desirable plant root traits for protecting natural and engineered slopes against landslides. Plant and Soil, $324(1-2): 1-30$. https://doi.org/10.1007/s11104-009-0159-y

33. Van Oost K., Bakker M. M. 2012. Soil productivity and erosion. Wall D. H. et al. (eds). Soil ecology and ecosystem services. Oxford, UK, p. 301-314. https://doi.org/10.1093/ acprof:oso/9780199575923.003.0027

34. Vanmaercke M., Maetens W., Poesen J., Jankauskas B., Jankauskiene G., Verstraeten G., de Vente J. 2012. A comparison of measured catchment sediment yields with measured and predicted hillslope erosion rates in Europe. Journal of Soils and Sediments, 12 (4): 586-602. https://doi.org/10.1007/s11368-012-0479-z

35. Wainwright J., Parsons A. J., Schlesinger W. H. 2002. Hydrology-vegetation interactions in areas of discontinuous flow on a semi-arid bajada, Southern New Mexico. Journal of Arid Environments, 51 (3): 319-338. https://doi.org/10.1006/jare.2002.0970

36. WRB. 2014. World reference base for soil resources. World Soil Resources Reports No. 106. FAO, p. 187-189.

37. Wu S., Wu P., Feng H., Merkley G. P. 2011. Effects of alfalfa coverage on runoff, erosion and hydraulic characteristics of overland flow on loess slope plots. Frontiers of Environmental Science and Engineering, 5 (1): 76-83. https://doi.org/10.1007/s11783-011-0282-x

ISSN 1392-3196 / e-ISSN 2335-8947

Zemdirbyste-Agriculture, vol. 107, No. 3 (2020), p. 209-216

DOI 10.13080/z-a.2020.107.027

\title{
Trumpalaikių ir ilgalaikių žolynų šaknų vystymasis ir priešerozinė reikšmė kalvotame reljefe
}

\author{
R. Skuodienè ${ }^{1}$, I. Kinderienè $\dot{1}^{1}$, D. Tomchuk ${ }^{1}$, J. Šlepetys², D. Karčauskienè ${ }^{1}$ \\ ${ }^{1}$ Lietuvos agrarinių ir miškų mokslų centro Vèžaičių filialas \\ ${ }^{2}$ Lietuvos agrarinių ir miškų mokslų centro Žemdirbystės institutas
}

\section{Santrauka}

Tyrimo tikslas - nustatyti žolynų šaknų vystymosi pokyčius skirtingai eroduotuose ekotopuose ir ịtaką šlaito stabilumui. Eksperimentas buvo irengtas LAMMC Véžaičiu filiale. Šiaurinès ekspozicijos šlaito dirvožemis - menkai eroduotas nepasotintasis balkšvažemis. Pietinès ekspozicijos šlaito dirvožemis dẻl labai stiprios erozijos viršutinėje dalyje pereina ị tipingą smarkiai eroduotą pasotintaji pradžiažemį. Kalvos ekspozicijos (pietinès ekspozicijos nuolydis $12-14^{\circ}$, šiaurinès

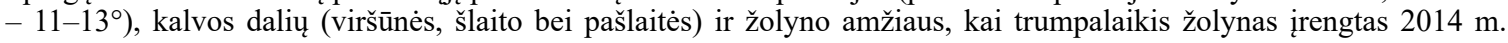
(mèlynžiedè liucerna (Medicago sativa L.) $50 \%+$ pašarinis motiejukas (Phleum pratense L.) $35 \%$ + pievinè miglè (Poa pratensis L.) $15 \%$ ), o ilgalaikis - 1983 m. (pašarinis motiejukas (Phleum pratense L.) 20 \%, raudonasis eraičinas (Festuca rubra L.) $20 \%$, pievinè migle (Poa pratensis L.) $20 \%$, baltasis dobilas (Trifolium repens L.) $20 \%$, paprastasis gargždenis (Lotus corniculatus L.) $20 \%$ ), ịtaka šaknų vystymuisi buvo nevienoda. Šaknų masei esminès įtakos turèjo žolyno amžius: pirmaisiais tyrimo metais ilgalaikis žolynas sukaupe 13,4 karto daugiau šaknų nei trumpalaikis. Formuojantis trumpalaikiam žolynui šaknų masès skirtumai nuosekliai mažèjo, o trečiaisiais tyrimo metais skirtumų nebuvo. Didžiausia (80-90 \%) tirtų žolynų šaknų masės dalis nustatyta dirvožemio 0-10 cm sluoksnyje. Šaknų bendrasis ilgis iš esmès didesnis buvo šlaito papèdeje, o vidutiniam šaknų skersmeniui kalvos ekspozicijos ir šlaito dalys ịtakos neturejjo. Kalvų šlaitams vandens erozija neturejjo neigiamos įtakos, kai tausojamosiose agrosistemose buvo auginti daugiamečiai žolynai ir ịrengtos žolių bei javų sejjomainos su trumpalaikiais žolynais. 